\title{
PERANCANGAN SISTEM INFORMASI AKADEMIK SEKOLAH BERBASIS WEB PADA SMP NEGERI 1 PULAU MOROTAI
}

\section{THE DESIGN OF WEB-BASED SCHOOL ACADEMIC INFORMATION SYSTEM AT SMP NEGERI 1 MOROTAI ISLAND}

\author{
Miswar Papuangan ${ }^{1}$, Imam Hizbullah ${ }^{2}$, Afendi Doe ${ }^{3}$ \\ Program Studi Teknik Informatika, Fakultas Teknik \\ Universitas Pasifik Morotai \\ miswarpapuangan@gmail.com
}

\begin{abstract}
Abstrak
Teknologi informasi dan komunikasi sangat penting dalam berbagai aspek kehidupan sehari-hari, sehingga hampir semua tugas kegiatan membutuhkan adanya fasilitas teknologi informasi dan komunikasi. Penyampaian informasi yang masih kurang maksimal di SMP Negeri 1 Pulau Morotai, sehingga membuat orang tua wali siswa, dan umumnya masyarakat mengalami kesulitan untuk mendapatkan informasi berkaitan dengan penerimaan siswa baru dan informasi akademik sekolah lainnya. Metode pengembangan sistem yang digunakan untuk merancang sistem informasi akademik sekolah pada SMP Negeri 1 Pulau Morotai adalah model waterfall. Model waterfall digunakan untuk memodelkan suatu sistem perangkat lunak yang dibuat secara terstruktur. Hasil perancangan sistem informasi akademik sekolah berbasis web pada SMP Negeri 1 Pulau Morotai menggunakan perangkat lunak $H T M L, P H P$, dan $M y S Q L$ dapat membantu para orang tua wali siswa dan masyarakat umumnya dalam mencari informasi tentang penerimaan siswa baru dan informasi akademik lainnya. Hasil pengujian sistem yang telah dilakukan, sistem menunjukan bahwa semua fungsi yang terdapat di dalam sistem dapat berjalan dengan baik.
\end{abstract}

Kata Kunci: Sistem Informasi, Akademik Sekolah, Web.

\begin{abstract}
Information and communication technology are essential in various aspects of daily life, so that almost all task activities require the existence of information and communication technology facilities. Submission of information that is still not optimal at SMP Negeri 1 Morotai Island, making parents guardians of students, and generally, the public has difficulty getting information relating to the admission of new students and other school's academic knowledge. The system development method used to design the school's educational information system at SMP Negeri 1 Morotai Island is the waterfall model. The waterfall model is used


to model a software system that is structured. The results of the design of a webbased school academic information system at SMP Negeri 1 Morotai Island using HTML, PHP, and MySQL software can help parents or guardians of students and the general public in finding information about admission of new students and other academic information. The results of system testing that has been done, the system shows that all functions contained in the network can run well.

\section{Keywords: Information Systems, School Academic, Web.}

\section{PENDAHULUAN}

Teknologi informasi dan komunikasi sangat penting dalam berbagai aspek kehidupan sehari-hari, sehingga hampir semua tugas kegiatankegiatan membutuhkan adanya fasilitas teknologi informasi dan komunikasi. Program berbasis web dan jaringan internet merupakan salah satu penyediaan dan penyaluran informasi yang sangat penting seiring perkembangan teknologi saat ini dapat memudahkan dalam melakukan suatu tugas tertentu yang bersifat informasi dan data yang selama ini menjadi kendala dalam ruang gerak untuk saling memberikan dan menerima informasi dan komunikasi.

Penyampaian informasi yang masih kurang maksimal pada SMP Negeri 1 Pulau Morotai membuat siswa, orang tua wali siswa dan masyarakat pada umumnya masih mengalami kendala dan kesulitan mendapatkan penerimaan siswa baru dan informasi akademik sekolah lainnya di SMP Negeri 1 Pulau Morotai.

Untuk mendapatkan Informasi, yang berangkutan harus datang dan menanyakan langsung kepada pihak sekolah. Kendalanya adalah ketika berada pada jarak yang cukup jauh, sehingga mengalami kesulitan untuk mendapatkan informasi penerimaan siswa baru dan infromasi akademik sekolah lainnya pada SMP Negeri 1 Pulau Morotai.

SMP Negeri 1 Pulau Morotai adalah sekolah yang berdiri sudah sejak lama, maka sudah seharusnya untuk SMP Negeri 1 Pulau Morotai memiliki sistem penyampaian informasi yang berbasis website ataupun dalam penerimaan siswa baru sudah harus memiliki sistem secara online sehingga memudahkan orang tua siswa untuk melakukan pendaftaran secara online dan mendapatkan informasi akademik lainnya.

Perancangan sistem informasi akademik sekolah berbasis pada SMP Negeri 1 Pulau Morotai yang dibangun, diharapakan dapat membantu pihak sekolah khususnya SMP Negeri 1 Pulau Morotai dalam mengelola kegiatan akademik sekolah yang terorganisir dan membantu pihak sekolah dalam menyalurkan informasi 
pendafataran dan penerimaan siswa baru secara online.

\section{LANDASAN TEORI}

\section{Konsep Dasar Sistem}

Suatu sistem mempunyai sifat-sifat tertentu, yaitu mempunyai komponenkomponen, batas sistem, lingkungan luar sistem, penghubung, masukan, proses, keluaran dan sasaran atau tujuan [1]. Dalam sistem terdapat bagian-bagian pendekatan dalam mendefinisikan sistem itu sendiri, yaitu yang menekankan pada prosedur dan pada komponen atau elemennya.

Sistem adalah suatu jaringan kerja dari prosedur-prosedur yang saling berhubungan, berkumpul bersamasama untuk melakukan suatu kegiatan atau untuk menyelesaikan suatu sasaran tertentu [1].

\section{Konsep Dasar Informasi}

Secara etimologi, kata informasi berasal dari kata bahasa perancis kuno informacion, sedangkan dari bahasa latin yaitu informationem yang berarti konsep, ide, atau garis besar. Informasi merupakan kata benda dari informare yang berarti aktivitas dalam pengetahuan yang dikomunukasikan [2].

\section{Siklus Informasi}

Siklus informasi adalah gambaran secara umum mengenai proses terhadap data sehingga menjadi informasi yang bermanfaat bagi pengguna. Proses menghasilakan informasi harus melalui tahapantahapan yang dilakukan komputer sebagai teknologi informasi. Tahapan-tahapan tersebut terdiri dari input-process-output, yang disebut sebagai siklus proses informasi. Informasi yang dihasilkan dapat pula dijadikan data kembali sebagai input untuk diproses selanjutnya. Siklus informasi ditunjukan pada gambar 1.

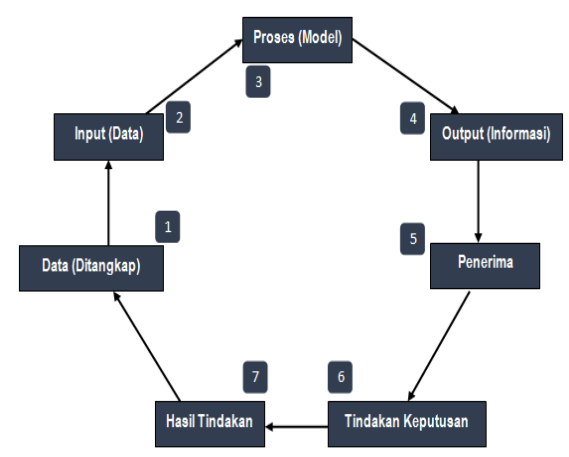

Gambar 1. Siklus Informasi

\section{Sistem Informasi}

Sistem informasi merupakan suatu sistem di dalam suatu organisasi yang mempertemukan kebutuhan pengolahan transaksi harian, mendukung operasi, bersifat manajerial, dan kegiatan strategi dari suatu organisasi dan menyediakan pihak luar tertentu dengan laporan-laporan yang diperlukan [3].

Sistem informasi juga dikatakan sebagai suatu kombinasi orang, perangkat keras, perangkat lunak, 
jaringan komunikasi, dan basis data yang mengumpulkan, mengubah, dan menyebarkan informasi dalam suatu bentuk organisasi [4].

\section{Data Flow Diagram (DFD)}

Data Flow Diagram merupakan alat yang digunakan untuk membuat diagram yang serbaguna. DFD terdiri dari notasi penyimpanan data, proses, aliran data, dan sumber masukan (entity) [5].

\section{Basis Data}

Basis data adalah kumpulan dari tabel-tabel yang saling berelasi, disusun secara logis, sehingga menghasilkan informasi yang bernilai dalam proses pengambilan keputusan [6]. Metode Entity Relationship yang berisi komponen-komponen himpunan entitas dan himpunan relasi yang masing-masing dilengkapi dengan atribut-atribut yang merepresentasikan seluruh fakta, dapat digambarkan dengan lebih sistematis menggunakan Entity Relationship Diagram (ERD).

\section{Konsep Dasar Website}

Dalam mencari informasi di internet, pengguna akan menuju ke sebuah alamat unik internet yang disebut nama domain dan menemukan informasi berbentuk teks, gambar diam atau bergerak, animasi bergerak, suara ataupun video dalam sebuah media, yang di sebut dengan website atau situs. Website dibentuk melalui sebua program penjelajah yang berada di sebuah komputer. Web adalah salah satu layanan yang didapat oleh pemakai komputer yang terhubung ke internet [7].

Web merupakan sebuah sistem penyebaran informasi melalui internet. Halaman website biasanya berupa dokumen yang ditulis dalam format Hyper Text Markup Language (HTML), yang bisa diakses melalui HTTP. HTTP adalah suatu protocol yang menyampaikan berbagai informasi dari server website untuk ditampilkan kepada pada user atau pemakai melalui web browser [8].

\section{METODE PENELITIAN Analisa Kebutuhan Sistem}

Kebutuhan dari sistem yang dibangun dalam perancangan sebuah sistem ini berdasarkan kebutuhan sekolah dengan melakukan penelitian sesuai ketentuan-ketentuan dalam perancangan suatu sistem baru agar mudah dijalankan dan dioperasikan. Sistem yang dirancang dengan menggunakan software bahasa pemograman web yang sesuai dengan kebutuhan sistem, diantaranya $H T M L, \quad P H P$ dan $M y S Q L$ dengan tambahan CSS dan Java Script untuk memperindah sistem yang dibangun.

Perancangan sistem informasi ini dibangun untuk mempermudah 
masyakarat yang berada ditempat dimana saja akan bisa mendapatkan informasi penerimaan siswa baru atau informasi akademik sekolah lainnya pada SMP Negeri 1 Pulau langsung dapat diakses melalui website SMP Negeri 1 Pulau Morotai. sistem ini dirancang akan sangat bermanfaat khususnya bagi para siswa yang baru menyelesaikan pendidikannya pada tingkat sekolah dasar dan hendak melanjutkan ke tingkat SMP yang ingin mendaftarkan diri sebagai calon siswa baru telah dipermudahkan, sehingga meskipun keberadaan siswa dan orang tua siswa pada jarak cukup jauh maupun yang berada diluar Pulau Morotai tetap dapat melakukan pendaftaran.

\section{Metode Pengembangan Sistem}

Metode pengembangan sistem yang digunakan adalah model waterfall. Model waterfall adalah suatu model proses untuk memodelkan suatu sistem perangkat lunak yang dibuat secara terstruktur [9]. Bagan dari model waterfall ditunjukan pada gambar 2 .

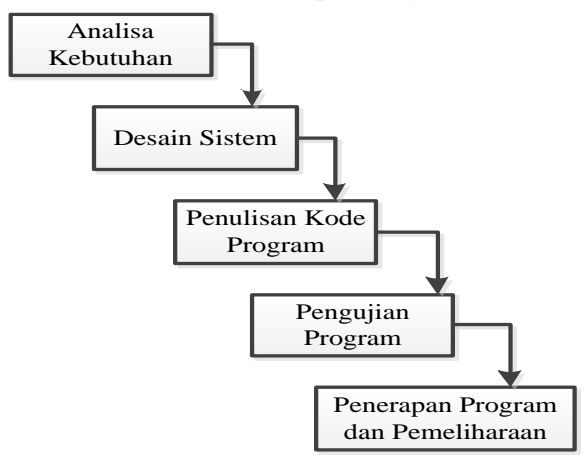

Gambar 2. Model Waterfall

\section{Diagram Konteks}

Diagram konteks merupakan level tertinggi dari data flow diagram yang menggambarkan suatu sistem terkait dengan dokumen input dan output serta entitas-entitas yang berhubungan dengan sistem yang dibangun [10].

Diagram konteks terdiri dari suatu proses dan menggambarkan ruang lingkup suatu sistem [11]. Perancangan sistem informasi berbasis web pada SMP Negeri 1 Pulau Morotai ini berhubungan dengan dua entitas pengguna, yaitu user dan admin. Diagram konteks ditunjukan pada gambar 3 .

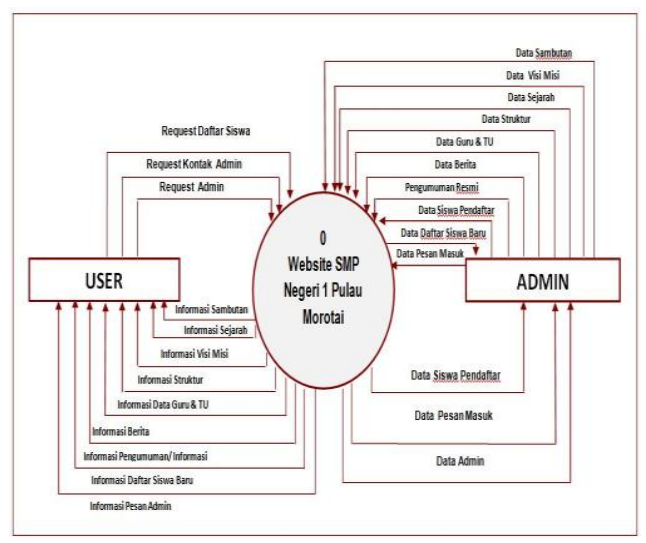

Gambar 3. Diagram Konteks

User memasukkan data-data ke dalam sistem berupa data pemohon yang dibutuhkan. Sedangkan admin merupakan entitas pengguna sistem yang berhubungan dengan tata kelola sistem.

\section{Diagram Alir Pendaftar}

Diagram alir pendaftar dapat dilihat pada gambar 4 . 


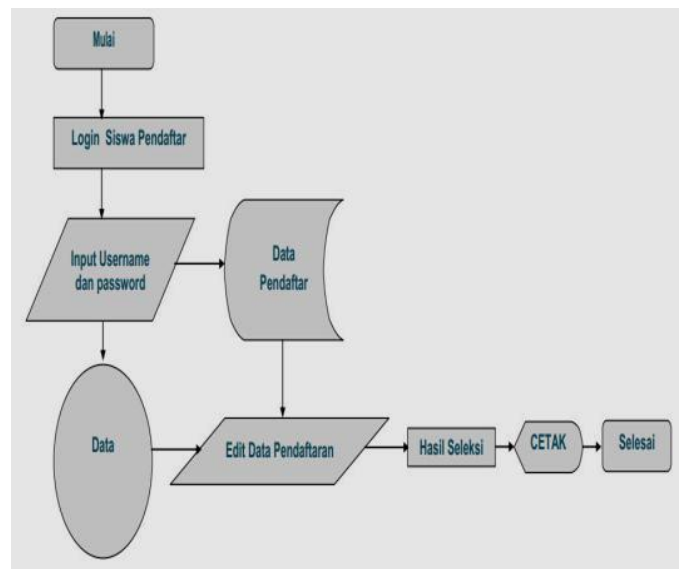

Gambar 4. Diagram Alir Pendaftar

\section{Diagram Alir Administrator}

Diagram alir administrator dapat dilihat pada gambar 5 .

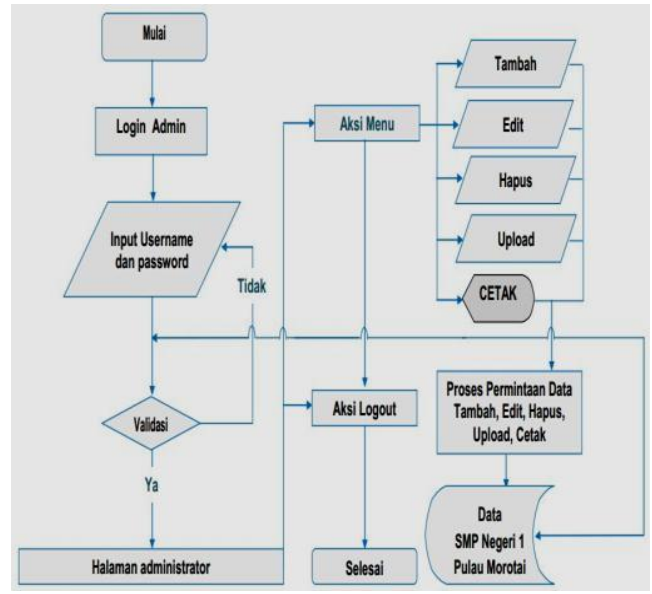

Gambar 5. Diagram Alir Administrator

\section{Entity Relationship Diagram (ERD)}

Entity Relationship Diagram berisi komponen-komponen himpunan entitas dan himpunan relasi yang masing-masing dilengkapi dengan atribut-atribut yang merepresentasikan seluruh fakta, yang dapat digambarkan dengan lebih sistematis. ERD dapat dilihat pada gambar 6 .

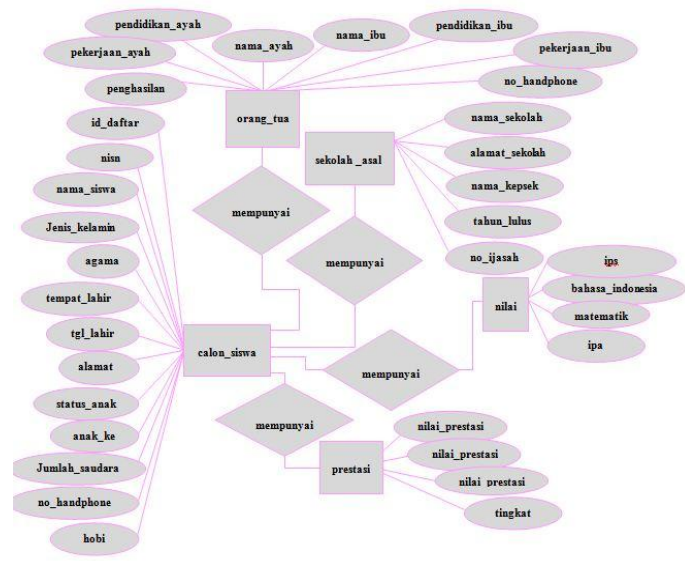

Gambar 6. ERD Sistem Website SMP Negeri 1 Pulau Morotai

\section{HASIL DAN PEMBAHASAN Antar Muka Sistem}

Perancangan sistem informasi pada SMP Negeri 1 Pulau Morotai memiliki dua level pengguna sistem yaitu user dan admin. Tampilan halaman utama dapat dilihat pada gambar 7. Di mana menu utama menyediakan menu-menu seperti sambutan kepala sekolah, sejarah sekolah dan visi misi, struktur sekolah, data guru dan pengumuman rasmi dari kepala sekolah dalam bentuk tuliusan yaitu sebuah surat resmi kepala sekolah. Kemudian juga menu berita sekolah yang menyajikan berita khusus berita sekolah yang dapat diakses publik. Terdapat juga menu daftar siswa baru, kontak, admin login pendaftar dan login admin. Dan juga menampilkan kalender. 


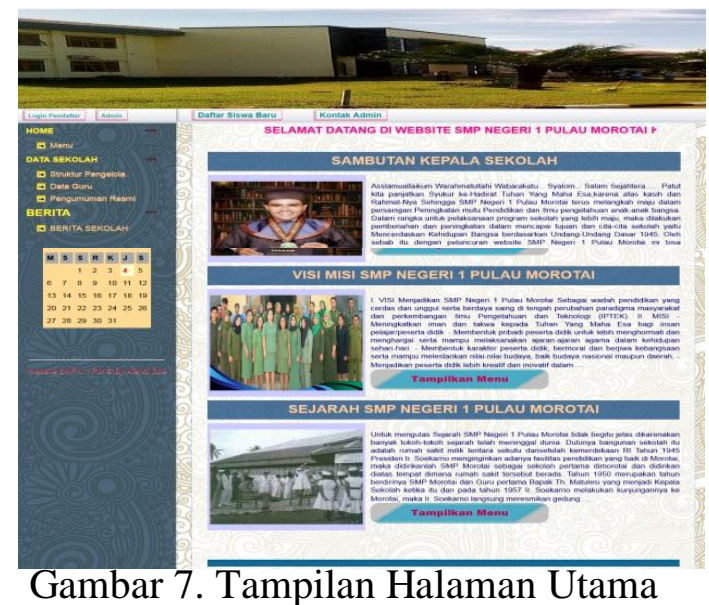

\section{Data Sekolah}

Pada menu data sekolah, terdapat menu struktur sekolah, data guru dan pengumuman resmi. Data sekolah dapat dilihat pada gambar 8, struktur sekolah dapat dilihat pada gambar 9, dan pengumuman resmi dapat dilihat pada gambar 10 .

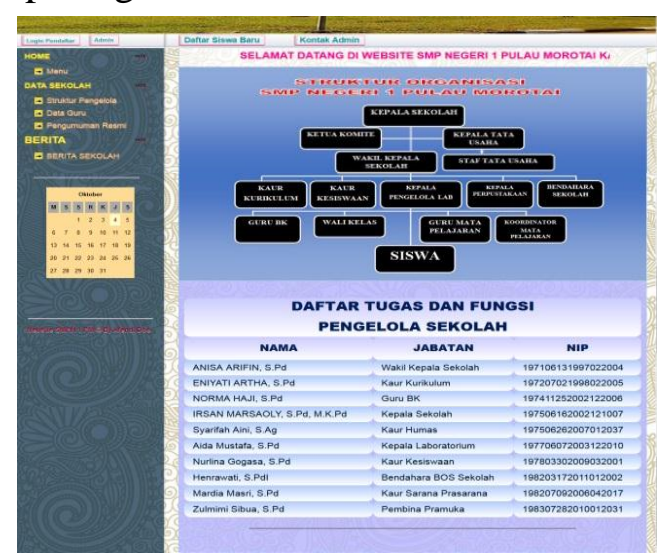

Gambar 8. Tampilan Struktur

Sekolah

Struktur pengelola yang ditampilkan ini sesuai dengan yang telah diputuskan dalam pertemuan bersama dewan guru bersama kepala sekolah SMP Negeri 1 Pulau Morotai.

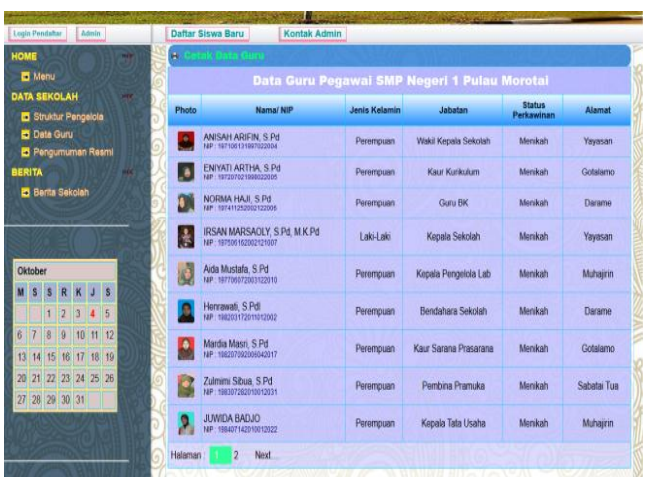

Gambar 9. Tampilan Daftar Data Guru

Form data guru menampilkan data guru yang menyajikan beberapa informasi seperti nama guru, NIP, jabatan, status, dan alamat.

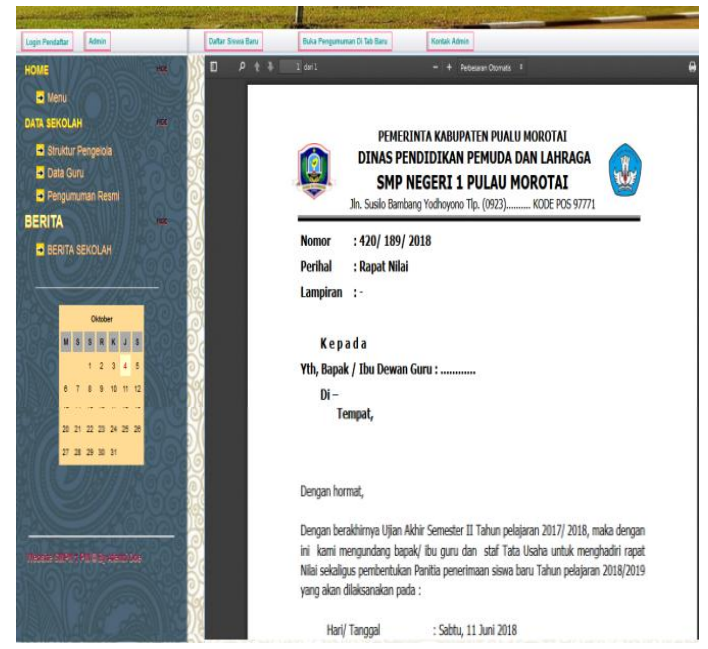

Gambar 10. Tampilan

Pengumuman Resmi

Form pengumuman resmi dirancang untuk menyediakan kebutuhan kepegawaian yakni dewan guru dan tata usaha agar dapat menerima informasi resmi secara internal sebagai pemberitahuan kepada seluruh 
dewan guru dan tata usaha untuk diketahui.

\section{Menu Daftar Siswa Baru}

Pada menu daftar siswa baru di sediakan untuk pendaftaran siswa baru. Form penerimaan siswa baru berfungsi untuk menerima pendaftaran siswa baru secara online dengan cara masuk ke menu daftar siswa baru. Form pendaftaran siswa dapat dilihat pada gambar 11 .

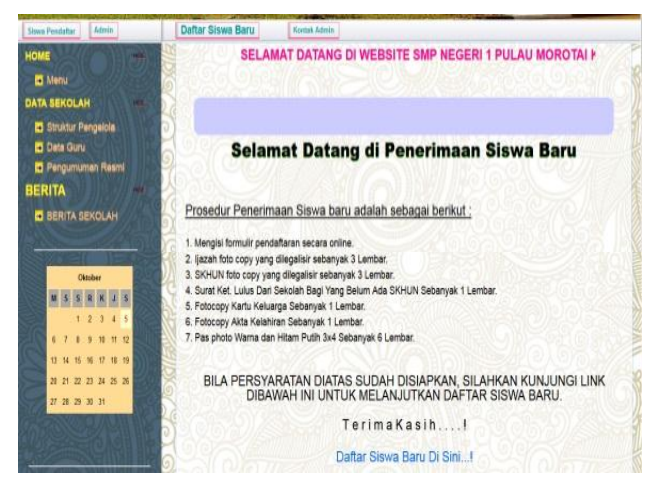

Gambar 11. Tampilan Form Daftar Siswa Baru

\section{Formulir Pendaftaran Siswa Baru}

Untuk dapat mengunjungi halaman Formulir pendaftaran siswa baru, maka klik menu daftar siswa baru maka akan muncul formulir pendaftaran, jika sudah selesai mengisi data diformulirnya secara keseluruhan dan setelah selesai, maka lagkah selanjutnya adalah melakukan proses pengiriman data. Formulir pendaftaran siswa baru dapat dilihat pada gambar 12.

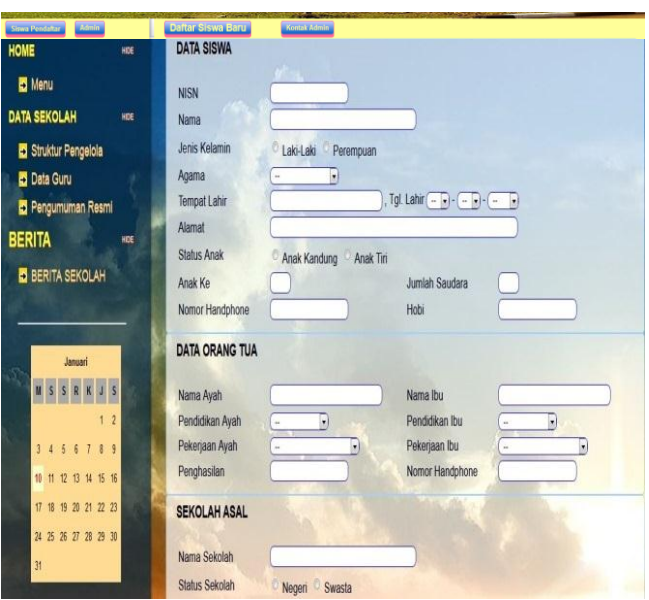

Gambar 12. Tampilan Formulir Pendaftaran Siswa Baru

\section{Form Cetak Formulir \\ Pendaftaran}

Pada laman pendaftar disediakan juga menu untuk form cetak formulir. Form cetak formulir dapat lihat pada gambar 13 .

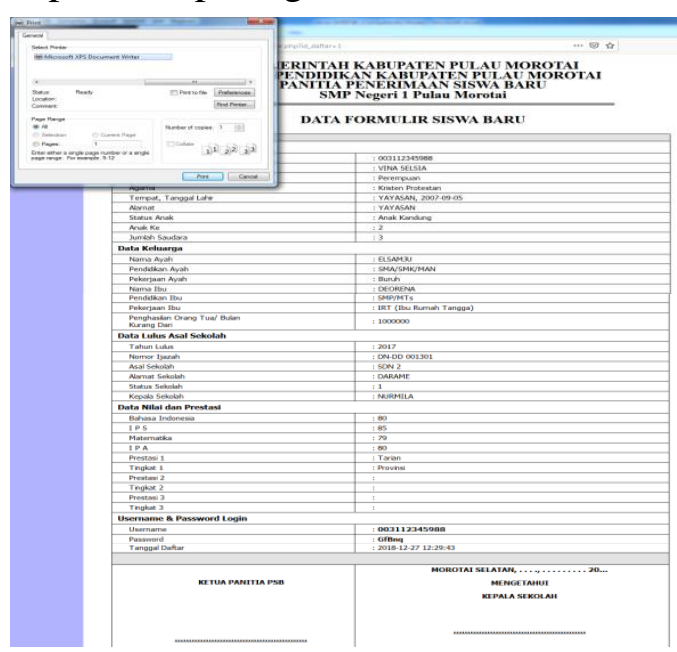

Gambar 13. Tampilan Form Cetak Formulir Pendaftaran

\section{Menu Login Pendaftar}

username dan password secara otomatis diperoleh siswa ketika 
sudah melakukan registrasi. username dan password yang sudah diperoleh kemudian digunakan untuk login pendaftar. Menu login pendaftar dapat dilihat pada gambar 14 .

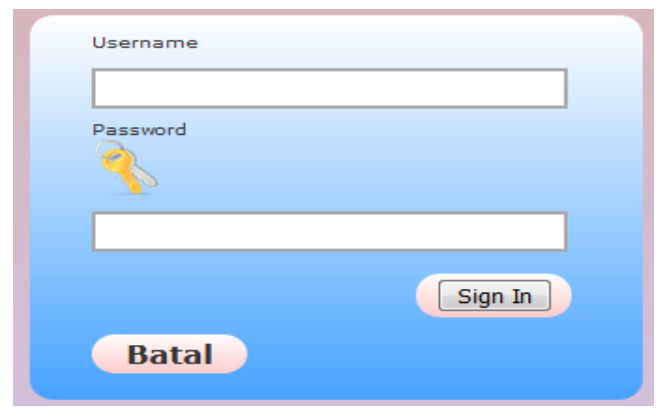

Gambar 14. Tampilan Menu Login Pendaftar

\section{Menu Login Admin}

Admin sebagai tata kelola sistem bisa melakukan manipulasi data (tamba, ubah, hapus). Menu login admin dapat dilihat pada gambar 15 .

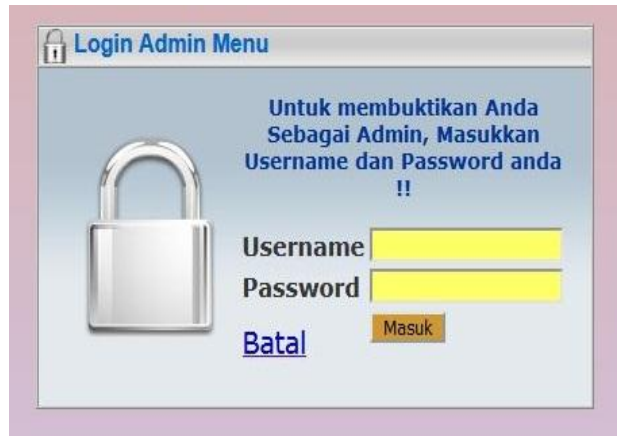

Gambar 15. Tampilan Menu Login Admin

\section{Halaman Depan Admin}

Halaman admin dirancang khusus admin yang dapat mengelola data. Sistem yang dirancang bersifat dinamis dan bisa di update sesuai kebutuhan di SMP Negeri 1 Pulau Morotai. Halaman admin dapat dilihat pada gambar 16.

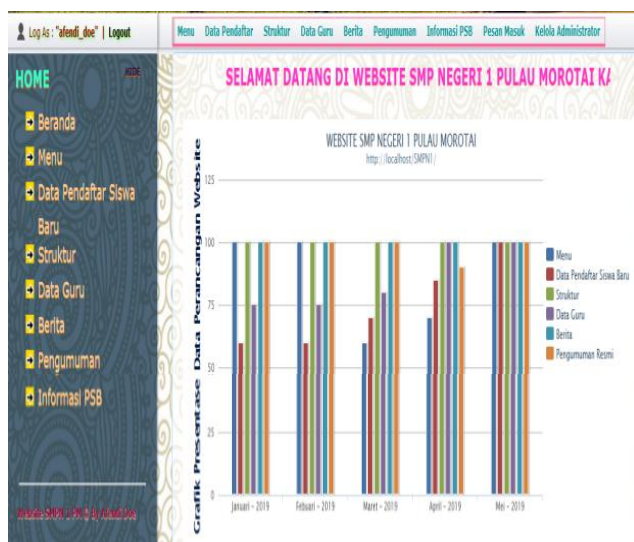

Gambar 16. Tampilan Halaman Depan Admin.

\section{Pengujian Sistem}

Pengujian dilakukan dengan menggunakan Black Box Testing (BBT). BBT digunakan untuk mengeksekusi sistem berdasarkan test case design yang telah dibuat untuk memeriksa fungsional sistem. Isi dari test case tersebut adalah kondisi input dan output yang diharapkan [12].

\section{Hasil Pengujian Program}

Tahapan uji coba program dilakukan dengan menggunakan metode pengujian yang dilakukan dengan mengamati hasil eksekusi dan memeriksa fungsional dari perangkat lunak. Hasil pengujian yang dilakukan ditunjukan pada tabel 1.

Tabel 1. Hasil Pengujian

Program

\begin{tabular}{|c|c|c|c|}
\hline $\begin{array}{c}\text { Kelas } \\
\text { Uji }\end{array}$ & $\begin{array}{c}\text { Test } \\
\text { Case }\end{array}$ & $\begin{array}{c}\text { Hasil yang } \\
\text { diharapkan }\end{array}$ & $\begin{array}{c}\text { Kesimp } \\
\text { ulan }\end{array}$ \\
\hline Daftar & Memilih & Menampil & valid \\
\hline
\end{tabular}




\begin{tabular}{|c|c|c|c|}
\hline $\begin{array}{l}\text { siswa } \\
\text { baru }\end{array}$ & $\begin{array}{l}\text { menu } \\
\text { daftar } \\
\text { siswa baru }\end{array}$ & $\begin{array}{l}\text { kan data } \\
\text { daftar } \\
\text { masuk }\end{array}$ & \\
\hline $\begin{array}{l}\text { User } \\
\text { pendaft } \\
\text { ar }\end{array}$ & $\begin{array}{l}\text { Memilih } \\
\text { menu login } \\
\text { pendaftar }\end{array}$ & $\begin{array}{l}\text { Menampil } \\
\text { kan halam } \\
\text { depan } \\
\text { laman } \\
\text { pendaftar }\end{array}$ & valid \\
\hline $\begin{array}{l}\text { Admin } \\
\text { (data } \\
\text { masuk } \\
\text { siswa } \\
\text { pendaf } \\
\text { atar) }\end{array}$ & $\begin{array}{l}\text { Memilih } \\
\text { tombol } \\
\text { cetak data } \\
\text { daftar } \\
\text { siswa }\end{array}$ & $\begin{array}{l}\text { Menampil } \\
\text { kan data } \\
\text { daftar } \\
\text { siswa }\end{array}$ & valid \\
\hline $\begin{array}{l}\text { Input } \\
\text { data } \\
\text { guru }\end{array}$ & $\begin{array}{l}\text { Memilih } \\
\text { menu } \\
\text { tamba data } \\
\text { guru }\end{array}$ & $\begin{array}{l}\text { Menampil } \\
\text { kan data } \\
\text { guru/pega } \\
\text { wai }\end{array}$ & valid \\
\hline $\begin{array}{l}\text { Input } \\
\text { berita }\end{array}$ & $\begin{array}{l}\text { Memilih } \\
\text { menu } \\
\text { berita } \\
\text { sekolah }\end{array}$ & $\begin{array}{l}\text { Menampil } \\
\text { kan } \\
\text { informasi } \\
\text { berita } \\
\text { sekolah } \\
\end{array}$ & valid \\
\hline $\begin{array}{l}\text { Admin } \\
\text { (uploa } \\
\text { d } \\
\text { pengu } \\
\text { muman } \\
\text { resmi }\end{array}$ & $\begin{array}{l}\text { Memilih } \\
\text { menu } \\
\text { pengumum } \\
\text { an resmi }\end{array}$ & $\begin{array}{l}\text { Menampil } \\
\text { kan } \\
\text { pengumum } \\
\text { an resmi }\end{array}$ & valid \\
\hline $\begin{array}{l}\text { Kontak } \\
\text { admin }\end{array}$ & $\begin{array}{l}\text { Memilih } \\
\text { menu } \\
\text { kontak } \\
\text { admin dan } \\
\text { mengirim } \\
\text { pesan }\end{array}$ & $\begin{array}{l}\text { Menampil } \\
\text { kan pesan } \\
\text { masuk ke } \\
\text { admin }\end{array}$ & valid \\
\hline
\end{tabular}

\section{KESIMPULAN}

Berdasarkan hasil perancangan hingga proses pengujian yang telah dilakukan pada perancangan sistem informasi akademik sekolah berbasis web pada SMP Negeri 1 Pulau Morotai dengan menggunakan perangkat lunak HTML, PHP dan MYSQL yang didalamnya telah dikembangkan dengan penerimaan siswa baru, sehingga teknologi informasi dan komunikasi yang masih kurang maksimal dapat teratasi.

Sistem yang dirancang bisa menjawab dan memenuhi tuntutan kebutuhan masyarakat khususnya orang tua wali siswa sebagai solusi untuk mendapatkan kemudahan diantaranya berupa informasi penerimaan siswa baru dan informasi akademik sekolah lainnya dan secara khusus dapat membantu para orang tua wali siswa serta umumnya masyarakat dalam mendaftarkan anaknya pada SMP Negeri 1 Pulau Morotai.

Hasil pengujian sistem yang telah dilakukan, sistem menunjukan bahwa semua fungsi yang terdapat di dalam sistem dapat berjalan dengan baik.

\section{DAFTAR PUSTAKA}

[1] Jogiyanto, H.M., 2005. Sistem Informasi Edisi 2. Andi, Yogyakarta.

[2] Supriyanto, A. 2005. Pengantar Teknologi Informasi. Salemba Infotek, Jakarta.

[3] Pressman, R. S., 2012. Rekayasa Perangkat Lunak Edisi 7. Gramedia, Yogyakarta.

[4] O'Brein, J. A., 2005. Pengantar Sistem Informasi. Salemba 4, Jakarta.

[5] Yakub. 2012. Pengantar Sistem Informasi. Graha Ilmu, Yogyakarta, ISBN 978-979756-807-8. 
[6] Kusdiawan. 2010. Pendataan Perpustakaan. Skripsi. Fakultas Teknik, Universitas Muhammadiyah Maluku Utara.

[7] Bertha, S., 2012. Pemrograman Web dengan PHP. Informatika, Bandung.

[8] Yuhefizar. 2013. Cara Mudah \& Murah Membangun \& Mengelola Website. Graha Ilmu, Yogyakarta.

[9] Dix, A. J. et al., 2003. HumanComputer Interaction, Third Edition. Prentice-Hall, USA.

[10] Papuangan, M., dan Salmin, M., 2019, Penggunaan Algoritma Nearest Neighbor Pada Sistem Penalaran Berbasis Kasus Untuk Diagnosis Penyakit ISPA. Jurnal Serambi Engineering, V, 1, 883892, ISSN: 2528-3561 (Print) 2541-1934 (Online)

[11] Papuangan, M., 2018, Penerapan Case Based Reasoning Untuk Sistem Diagnosis Penyakit Hepatitis. Jurnal Informatika dan Komputer (JIKO), 1, 1, 7-12, ISSN: 2614-8897 (Print) 26562945 (Online).

[12] Cabrera, M, M., dan Edye, E, O., 2010. Integration of Rule-Based expert Systems and Case-Based Reasoning in an Acute Bacterial Meningitis Clinical Decision Support System. International Journal of Computer Science and Information Security (IJCSIS), 7, 2. ISSN: 1947-5500. 